\title{
The effect of thickness and density of the recycled car tire panels on sound insulation
}

\author{
Anđelko Crnoja \\ Odessa State Academy of Civil Engineering and Architecture, Ph.D \\ acrnoja@hotmail.com \\ Željko Kos \\ University North, Ph.D \\ zeljko.kos@unin.hr \\ Evgeny Klymenko \\ Odessa State Academy of Civil Engineering and Architecture, prof. Ph.D \\ klimenkoew57@gmail.com \\ Iryna Grynyova \\ Odessa State Academy of Civil Engineering and Architecture, Ph.D \\ irene.grinyova@gmail.com
}

\begin{abstract}
The article is devoted to the task of improving sound insulation in the construction of internal walls. For the experiment purposes wall panels were used that are made using rubber crumb as a separate structural layer. The analysis of the influence of the frequency range on the value of the sound insulation index was carried out. The effect of the particle size distribution of the mixture and the thickness of the wall panel on its soundproofing characteristics was investigated. Based on the results obtained, a conclusion was drawn about the influence of specific gravity on the sound insulation index.
\end{abstract}

Keywords: sound insulation, recycled rubber panel, sound insulation index, frequency range, rubber crumb

\section{Učinak debljine i gustoće ploča od recikliranih automobilskih guma na zvučnu izolaciju}

Sažetak: Članak je posvećen zadatku poboljšanja zvučne izolacije u izgradnji unutarnjih zidova. U pokusu su korištene zidne ploče izrađene od gumenih mrvica kao zasebnog strukturnog sloja. Provedena je analiza utjecaja frekvencijskog područja na vrijednost indeksa zvučne izolacije. Istražen je utjecaj raspodjele veličina čestica smjese i debljine zidne ploče na karakteristike zvučne izolacije. Na temelju dobivenih rezultata zaključuje se o utjecaju specifične težine na indeks zvučne izolacije.

Ključne riječi: zvučna izolacija, ploča od reciklirane gume, indeks zvučne izolacije, frekvencijski raspon, gumena mrvica 
Crnoja, A., Kos, Ž., Klymenko, E., Grynyova, I.

The effect of thickness and density of the recycled car tire panels on sound insulation

\section{INTRODUCTION}

The daily use of transport equipment and the rapid annual increase in its quantity cause serious environmental problems. The element of an automobile that has the most significant negative impact on the environment is a rubber tire. To reduce this effect, the processing of such waste is necessary. Technological processing methods are relatively simple, cheap and raw materials are readily available. However, the issue of the use of such a product in a wider range of industries remains relevant. Therefore, the article is about the properties of recycled material from waste car tires for the production of panels for protection against unwanted sound.

Such panels can be used as an integral part of the design from the point of view of improving sound insulation properties, especially, in lightweight constructions. Lightweight constructions are characterized by good thermal insulation, high seismic resistance and a number of other properties that depend on production technology, but have a low sound insulation index. The problem of sound insulation of light metal or wooden interior walls and partitions is associated with the vibration of the layer of their cladding, which transfers vibrational movements directly to the structure.

During the design of residential buildings, one of the most important criteria for assessing the quality of the final product is to provide residents with acoustically comfortable conditions [4]. Certain public and municipal structures, according to the author [1], define some parts of cities as priority in terms of protection from noise and other environmental pollution and attach particular importance to this issue. Sound insulation of wall and multiapartment buildings is regulated by a number of building codes and regulations [4-11]. However, even when regulatory requirements are met, in some cases inconvenient acoustic conditions are observed [12].

In addition, in recent years in many countries, much attention has been paid to the problem of using production and consumption waste. Nowadays, recycling, sustainable architecture and design have become a top priority in our society. Billions of tons of solid waste are generated annually, which is a significant factor in the negative impact on the environment. They can and should be used as cheap, durable and environmentally friendly building materials.

One of the promising types of processing is the use of rubber in the form of dispersed materials. In particular, the use of crumb rubber in construction by adding rubber dispersions to concrete [13]. It should also be noted that recycled rubber can also be used as a complement to other materials to improve sound insulation. The author [2] published a study showing a certain effect of recycled rubber and its application in construction in the form of a Gum-Gum spray up to $7 \mathrm{~mm}$ thick. The purpose of the experiments is to analyze the possibility of using crumb rubber as one of the products of tire recycling in construction.

The main goal is to study the effect of the density and thickness of panels made of this material on the overall sound insulation of the structure. The experiments were carried out in such a way that a barrier was placed between the sound source and the sound receiver. Sound pressure levels can be measured using a variety of equipment. The author [3] used equipment that transmits single frequency signals and ultimately processes them and obtains usable results. This study was carried out on sophisticated noise-generating equipment containing a spectrum of all frequencies.

\section{MATERIALS AND METHODS}

All studies described in this work were carried out in accordance with the standard HRN EN ISO 717-1: 2013 [5]. This regulatory document regulates research methods and sound 
Crnoja, A., Kos, Ž., Klymenko, E., Grynyova, I.

The effect of thickness and density of the recycled car tire panels on sound insulation

insulation assessment in structural elements of buildings and takes into account various external and internal noise sources.

In the presented studies, the effect of changing the density and thickness of a panel with a constant particle size distribution was studied. 9 samples were selected, which, depending on a number of factors, were divided into 3 groups and compared with each other. Tables 13 show the combination of samples with constant and variable comparison factors.

Table 1. Group of samples № 1

\begin{tabular}{|c|c|c|c|}
\hline № & $\begin{array}{c}\text { Thickness of } \\
\text { sound } \\
\text { insulation } \\
\text { panel }(\mathrm{mm})\end{array}$ & $\begin{array}{c}\text { Weight of } \\
\text { sound } \\
\text { insulation } \\
\text { panel }\left(\mathrm{kg} / \mathrm{m}^{3}\right)\end{array}$ & Grading \\
\hline 1. & 10 & 700 & $05-20$ \\
\hline 2. & 10 & 900 & $05-20$ \\
\hline 3. & 10 & 1110 & $05-20$ \\
\hline
\end{tabular}

Table 2. Group of samples № 2

\begin{tabular}{|c|c|c|c|}
\hline № & $\begin{array}{c}\text { Thickness of } \\
\text { sound } \\
\text { insulation } \\
\text { panel }(\mathrm{mm})\end{array}$ & $\begin{array}{c}\text { Weight of } \\
\text { sound } \\
\text { insulation } \\
\text { panel } \\
\left(\mathrm{kg} / \mathrm{m}^{3}\right)\end{array}$ & Grading \\
\hline 4. & 15 & 600 & $05-20$ \\
\hline 5. & 15 & 750 & $05-20$ \\
\hline 6. & 15 & 916 & $05-20$ \\
\hline
\end{tabular}

Table 3. Group of samples № 3

\begin{tabular}{|c|c|c|c|}
\hline № & $\begin{array}{c}\text { Thickness of } \\
\text { sound } \\
\text { insulation } \\
\text { panel }(\mathrm{mm})\end{array}$ & $\begin{array}{c}\text { Weight of } \\
\text { sound } \\
\text { insulation } \\
\text { panel } \\
\left(\mathrm{kg} / \mathrm{m}^{3}\right)\end{array}$ & Grading \\
\hline 7. & 20 & 585 & $05-20$ \\
\hline 8. & 20 & 750 & $05-20$ \\
\hline 9. & 20 & 915 & $05-20$ \\
\hline
\end{tabular}

Along with this, measurements of sound insulation panel were carried out for various frequency ranges: low (up to $500 \mathrm{~Hz})$, medium $(500-2000 \mathrm{~Hz})$ and high $(2000-5000 \mathrm{~Hz})$. 
Crnoja, A., Kos, Ž., Klymenko, E., Grynyova, I.

The effect of thickness and density of the recycled car tire panels on sound insulation

\section{EXPERIMENT}

The experiment was conducted at the Laboratory for Building Physics and Acoustic Testing of the Civil Engineering Institute (CEI) of Croatia.

The room with the sound receiver was completely separated from the room where the sound source was located. The existing opening in the wall between the rooms was designed to test the soundproof properties of windows and doors. The area of the experimental samples was $0.75 \mathrm{~m}^{2}$, which corresponds to the size of the window opening. The samples were built into a box similar to a window block [Fig. 1, 2].

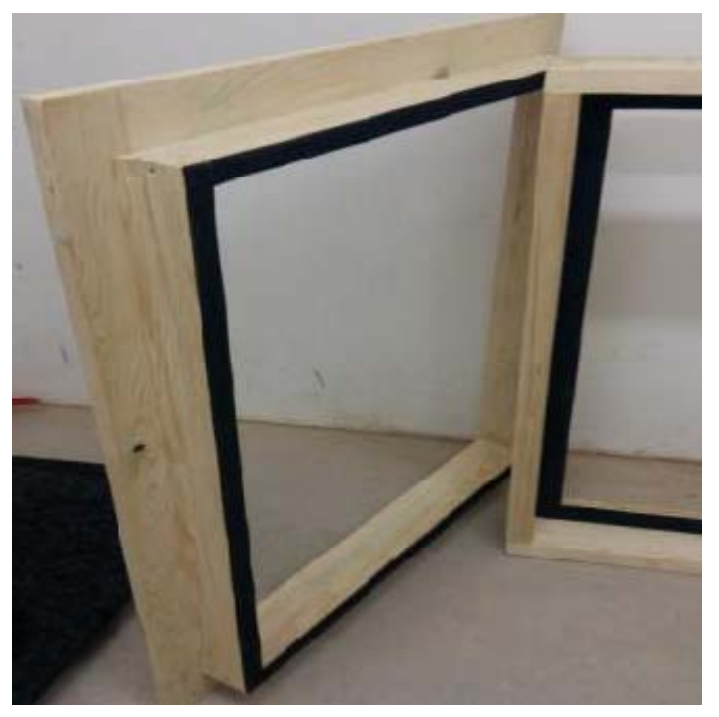

Figure 1. General view of soundproof panels

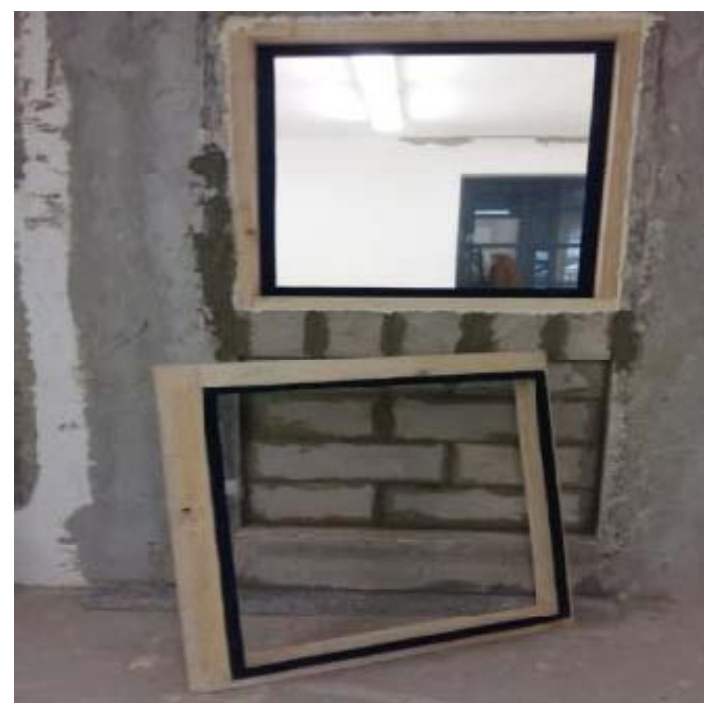

Figure 2. Installation of soundproof panels during the experiment

The soundproofing value of the partition between the receiver room and the transmitter room was approximately $75 \mathrm{~dB}$. According to the regulatory document [5], it is necessary that the value of sound insulation due to the test sample differ by at least $10 \mathrm{~dB}$. In this case, 
Crnoja, A., Kos, Ž., Klymenko, E., Grynyova, I.

The effect of thickness and density of the recycled car tire panels on sound insulation

during the tests, it was necessary to ensure such conditions that the sound insulation value of the dividing structure didn't influence the results.

To ensure a complete separation of the transmitter and the receiving room and to prevent any possible transmission of sound or sound vibrations, the laboratory structures were constructed without interconnected elements. To prevent the occurrence of sound bridges that would impair the reliability of the test samples, all joints were designed to be air permeable to comply with regulatory requirements.

The panels used in the experiment were manufactured by the company Gumi Impex (Varaždin, Croatia) at the tire recycling plant. Depending on the equipment of the plant and a number of technological solutions, they can be made of different thicknesses. The selected thickness of the samples was 10,15 and $20 \mathrm{~mm}$, which have been the first variable research factor. The second factor that varies is the mass of the samples, which are divided into four main groups: $600 \mathrm{~kg} / \mathrm{m}^{3}$, about $700 \mathrm{~kg} / \mathrm{m}^{3}$, about $900 \mathrm{~kg} / \mathrm{m}^{3}$ and about $1110 \mathrm{~kg} / \mathrm{m}^{3}$.

The equipment for testing must be located in places according to the plan of the experiment and their position must be observed during the experiment. The sound source had several positions in which it was placed during the measurement, while the microphone was on a rotating stand and its position didn't change. The sound receiver was a microphone on a special stand, which rotated in several planes and completely accumulated the sound that came from the transmitter [Fig. 3, 4, 5].

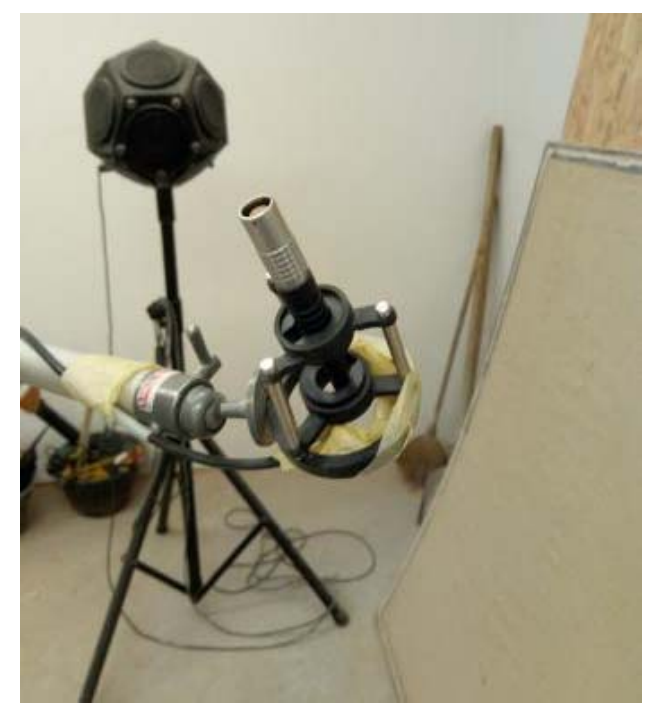

Figure 3. General view of the device for sound reproduction 
Crnoja, A., Kos, Ž., Klymenko, E., Grynyova, I.

The effect of thickness and density of the recycled car tire panels on sound insulation

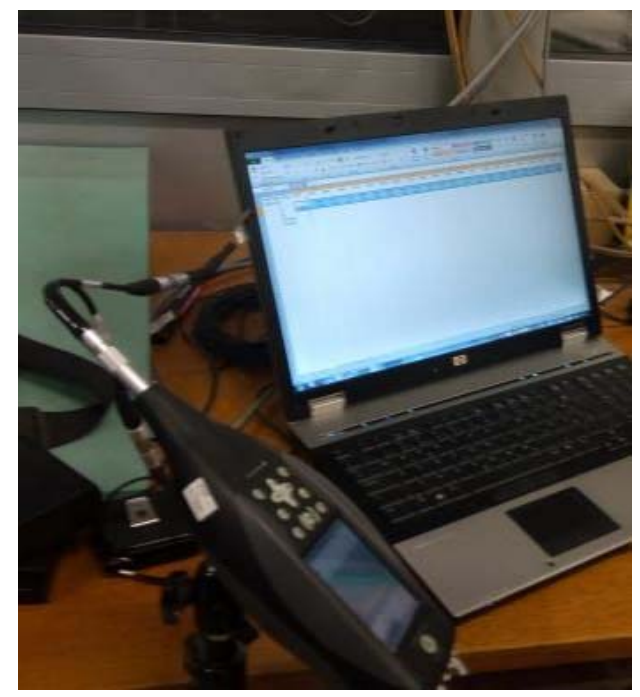

Figure 4. General view of the equipment for measurement and data analysis

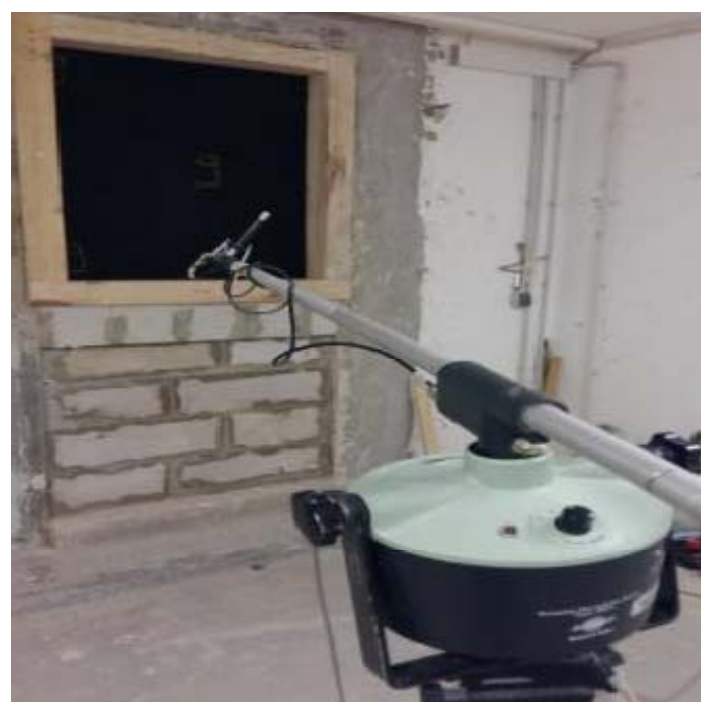

Figure 5. General view of the device for receiving sound during the test

The measurement was carried out in such a way that a sound power of about $105 \mathrm{~dB}$ was emitted for 60 seconds in two stages. A stationary noise of about $105 \mathrm{~dB}$ radiates from an unbalanced sound source for about 1 minute. The measurement was carried out 2 times for each sample. The computer processes the data, outputs the sound insulation value at the specified frequencies (in accordance with the standard) and, as a result, provides the final sound insulation value of the panel in relation to the sound of the antenna.

Comparison of such properties as the change in density relative to the factor of stable particle size distribution and variable thickness of the panel can provide data on the effect of specific gravity on the sound insulation index of the partition and recommendations for further tests. The results of experiments to determine the level of sound insulation are presented for each group separately in the form of diagrams [Fig. 6-8]. 
Crnoja, A., Kos, Ž., Klymenko, E., Grynyova, I.

The effect of thickness and density of the recycled car tire panels on sound insulation

COMPARISON OF PANEL RESULTS №1, 2,3

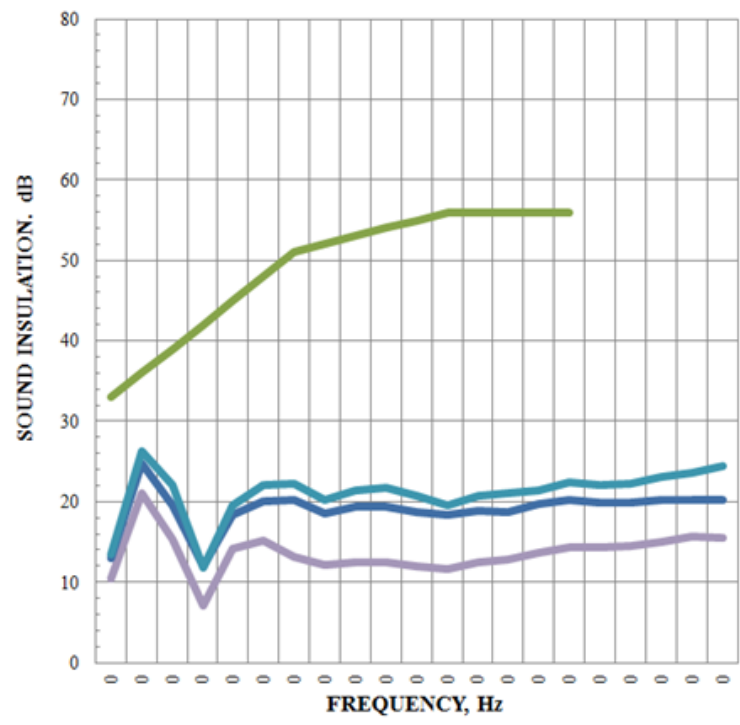

CONTROL CURVE PANEL №1 - Ri=14 dB

-PANEL №2 - Ri= $20 \mathrm{~dB} \longrightarrow$ PANEL №3 - Ri=22,1 dB

Figure 6 Group of samples №1

COMPARISON OF PANEL RESULTS № 4, 5, 6

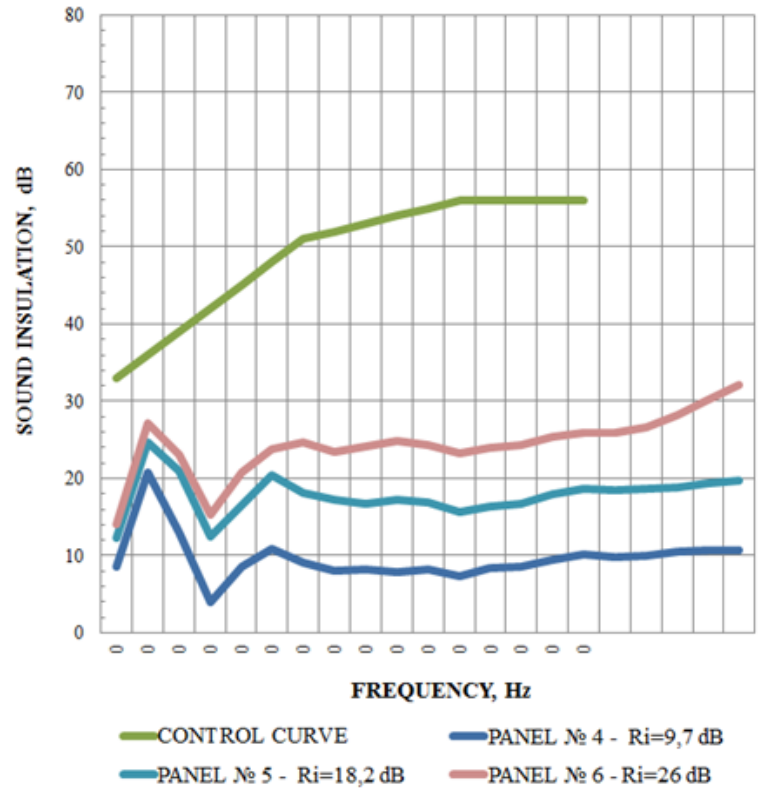

Figure 7. Group of samples №2 
Crnoja, A., Kos, Ž., Klymenko, E., Grynyova, I.

The effect of thickness and density of the recycled car tire panels on sound insulation

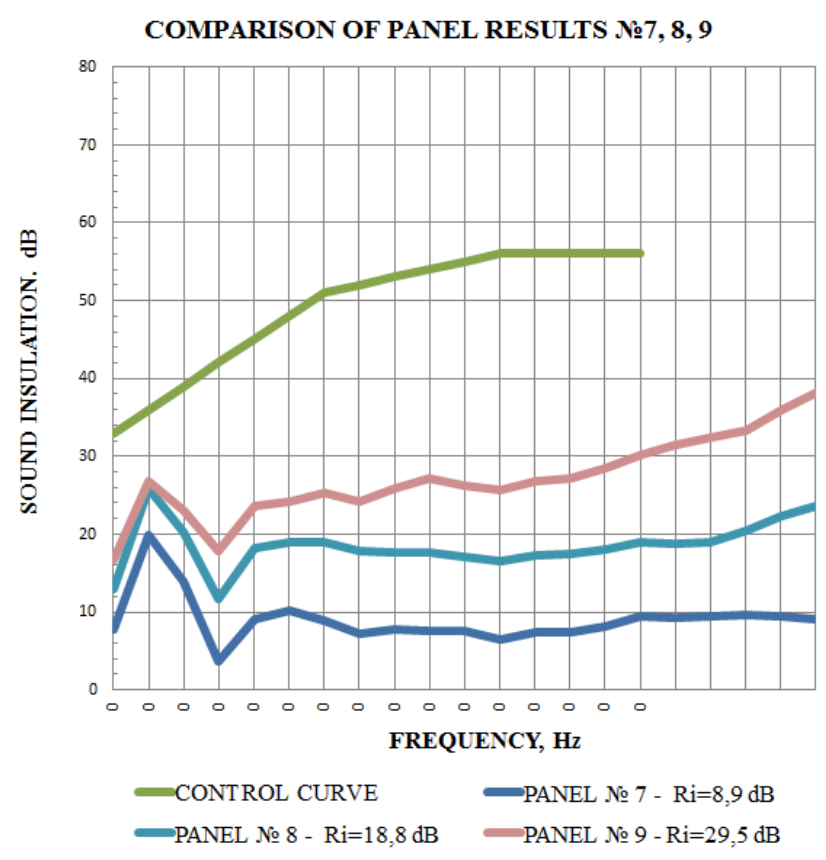

Figure 8. Group of samples №3

The relationship between the sound insulation values for each of the studied panels was shown in the diagrams. Graphically and visually, we could track the changes associated with the value of the sound reduction index of a particular sample and compare it with the control curve.

The test results made it possible to analyze the change in sound insulation indicators depending on the change in certain parameters. Namely, as the sound reduction index changed with the same sample thickness with a constant particle size distribution, the density also varied in different groups and samples.

\section{RESULTS}

The first group consists of three samples with a thickness of $10 \mathrm{~mm}$, particle size distribution of $0.5-2.0 \mathrm{~mm}$ and with different densities: sample No. $1-700 \mathrm{~kg} / \mathrm{m}^{3}$, No. $2-900 \mathrm{~kg} / \mathrm{m}^{3}$ and No. $3-1110 \mathrm{~kg} / \mathrm{m}^{3}$.

As can be seen from the presented diagrams (Fig. 7), samples 2 and 3 have a similar sound reduction index (measurement curves are very close), and sample 1 is much lower.

Based on the more detailed analyses, the results are presented in different frequency ranges and the following conclusions can be drawn:

- in the low-frequency range, panel 3 has better soundproofing properties, except for the frequency of $100 \mathrm{~Hz}$, where the soundproofing value is lower by $0.1 \mathrm{~dB}$ than in panel 2, and the average soundproofing of panel 3 is $7.08 \%$ better than in panel 2 . Panel 1 has an average sound insulation value $38.35 \%$ lower than panel 2 , and $47.96 \%$ lower compared than panel 3.

- in the mid-frequency range, panel 3 has the best sound insulation properties, better by $10.45 \%$ compared to panel 2 . Panel 1 has an average sound insulation value lower by $49.64 \%$ than panel 2 , and $65.24 \%$ compared to panel 3 . 
Crnoja, A., Kos, Ž., Klymenko, E., Grynyova, I.

The effect of thickness and density of the recycled car tire panels on sound insulation

- in the high-frequency range, the panel 3 better sound insulation properties and the sound insulation of the panel is $15.88 \%$ higher compared to panel 2 . Panel 1 has an average sound insulation value lower by $32.92 \%$ than panel 2 and $53.96 \%$ compared with panel 3 .

The second group consists of three samples with a thickness of $15 \mathrm{~mm}$, particle size distribution from 0.5 to $2.0 \mathrm{~mm}$ and different densities: sample No. $4-600 \mathrm{~kg} / \mathrm{m}^{3}$, No. 5 $750 \mathrm{~kg} / \mathrm{m}^{3}$ and sample No. $6-916 \mathrm{~kg} / \mathrm{m}^{3}$.

The overall result shows the same difference between samples 4 and 5 and between samples 5 and 6 . It is worth noting that there is a similar difference in volumetric weight between samples 4 and 5 and between samples 5 and 6 .

Based on the more detailed analyses, the results are presented in different frequency ranges, and the following conclusions can be drawn:

- in the low-frequency range, panel 6 has better sound insulation properties by $21.54 \%$ than panel 5 . Sound insulation of panel 4 has a lower value $-91.65 \%$ compared to panel 5 and $135.68 \%$ compared to panel 6.

- in the mid-frequency range, panel 6 has $43.51 \%$ better sound insulation compared to panel 4. Panel 4 has a sound insulation value of $99.44 \%$ lower compared to panel 5 and $186.39 \%$ compared to panel 6 .

- in the high-frequency range, panel 6 has $52.84 \%$ better sound insulation properties than panel 5. Panel 4 has a sound insulation value that is $82.87 \%$ lower than panel 5 and $179.45 \%$ lower than panel 6.

In the third group, we have three samples with a thickness of $20 \mathrm{~mm}$ with a particle size distribution of 0.5-2.0 mm and different densities: sample No. $7-585 \mathrm{~kg} / \mathrm{m}^{3}$, sample No. 8 $750 \mathrm{~kg} / \mathrm{m}^{3}$ and sample No. $9-915 \mathrm{~kg} / \mathrm{m}^{3}$.

The overall result shows the same difference between samples 7 and 8 and between samples 8 and 9 . There is also a similar difference in density between samples 7 and 8 and between samples 8 and 9 . Thus, the situation is similar to group 2 .

Based on the more detailed analyses, the results are presented in different frequency ranges, and the following conclusions can be drawn:

- in the low-frequency range, panel 9 has better sound insulation properties by $28.26 \%$ than panel 8 . Panel 7 has an average sound insulation rate lower $102.36 \%$ in relation to panel 8 and $157.23 \%$ in relation to panel 9 .

- in the mid-frequency range, panel 9 has $55.93 \%$ better sound insulation properties than panel 8 . The sound insulation value of panel 7 has a lower value by $126.43 \%$ compared to panel 8 and $252.57 \%$ in relation to panel 9.

- in the high frequency range, panel 9 has $64.28 \%$ better sound insulation than panel 8 . Panel 7 has a lower sound insulation value by $12.70 \%$ compared to panel 8 and $273.56 \%$ to panel 9.

\section{CONCLUSION}

The given measurement results show a significant effect of the imperfection of partitions on the sound reduction index. With increasing density, the sound reduction index increases proportionally.

Thus, panel No. 3 has better soundproofing properties compared to panel No. 2 by $10.50 \%$, and compared to panel No. 1 it is better by $57.86 \%$.

Panel No. 6 has better soundproofing properties compared to panel No. 5 by $42.86 \%$, and compared with panel No. 4 it is better by $168.04 \%$.

Panel No. 9 has better soundproofing properties compared to panel No. 8 by $56.91 \%$, and in comparison with panel No. 7 it is better by $231.46 \%$. 
Crnoja, A., Kos, Ž., Klymenko, E., Grynyova, I.

The effect of thickness and density of the recycled car tire panels on sound insulation

So, the change in density, regardless of the thickness of the panel, significantly affects the sound reduction indicator. Thus, the results of this study will certainly use further research on the optimal structure of rubber plates in a functional and decorative one-sided and two-sided combination with metal sheets.

\section{REFERENCES}

1. San'kov P.M., Tkach N.O., Dikarev K.B., Bliznyuk A.M., Gvadzhaia B. D.: Vpliv avtotransportu na robochi miscya $v$ merezhi ustanov obslugovuvannya (za faktorom shumu j zagazovanosti v centri mista Dnipro) (Effect of motor transport on the working places in the service infrastructure (By noise factor and urban air pollution in the center of the Dnipro city)) // Nauka innov. 2018, ISSN 1815-2066. 14(3)

2. Mindess, S., Young, J. F., Darwin, D. 2002: Concrete, 2nd edition, Prentice-Hall inc., New Jersey, https://scholar.google.com.ua/citations?user=nZVu_NoAAAAJ\&hl=ru

3. Babiy I.N., Gostrik A.N., Kal'chenya E.Yu., Mnogokriterial'nyj analiz pri vybore tekhnologii ustrojstva zvukoizolyacii mezhduetaznyh monolitnyh perekrityjo (Multiple criteria analysis when choosing the technology of the sound insulation device of the monolithic interflooring) // Visnik Pridniprovs'koï derzhavnoï akademiï budivnictva ta arhitekturi, 2018, № 4 (243-244) ISSN 2312-2676., https://scholar.google.com.ua/citations?user=MeOzLqwAAAAJ\&hl=ru

4. Kersh D.V., Lyashenko T.V., Kersh V.Ya. Analiz vliyaniya legkih zapolnitelej na zvukoizoliruyushchie svojstva gipsobetona (Analysis of the influence of light fillers on the sound insulating properties of gypsum concrete) // Odesskaya gosudarstvennaya akademiya stroitel'stva i arhitektury, Odessa. UDK 666:536, https://scholar.google.com.ua/citations?user=5PYuJWoAAAAJ\&hl=ru

5. Dementev V.V. O sub'ektivnyih otsenkah zvukoizolyatsii udarnogo shuma $v$ zhilyih zdaniyah // Naukoviy vlsnik budivnitstva. - Harklv: HDTUBA, HOTV ABU, 2018. - T.93, №. 3., P. 59-63.

6. HRN EN ISO 717-1:2013 Acoustics. Rating of sound insulation in buildings and of building elements

7. DSTU-N B V.1.1-34:2013 Nastanova z rozrahunku ta proektuvannya zvukolzolyatsii ogorodzhuvalnih konstruktsiy zhitlovih i gromadskih budinkiv. Kyiv: Minregion Ukrayinu, 2014.

8. ISO Recommendation $\mathrm{R}-717 / 2$ Rating of sound insulation in building and of building elements - impact sound insulation.

9. DSTU B EN 12354-1:2014 Stroitelnaya akustika. Opredelenie akusticheskih harakteristik zdaniy po harakteristikam ih elementov. Chast 1. Izolyatsiya vozdushnogo shuma mezhdu pomescheniyami (EN 12354-1:2000, IDT)

10. DBN V.1.1-31:2013 Zahist teritoriy, budinkiv i sporud vid shumu. - Kyiv, Minregion Ukrayinu, 2014, P. 48.

11. Zmina №4 Vidannya ofitsiyne do DBN V.2.2-15-2005 Zhitlovi budinki. Osnovni polozhennya - Kyiv, Minregion Ukrayinu, 2005

12. DBN V.1.2-10-2008 Zahist vid shumu. Osnovni vimogi do budivel i sporud. - Kyiv, Minregion Ukrayinu, 2008

13. Luneeva G.S. Otsenka bespokoyaschego vozdeystviya na prozhivayuschih $v$ zhilyih domah shumov, pronikayuschih iz sosednih kvartir i s ulitsyi // Zvukoizolyatsiya i zaschita ot shumov v zhilyih domah / TsNIIEP zhilischa. Moscow, 1984. P. 101-117.

14. Chernyshova E.P. Architectural town-planning factor and color environment / E.P. Chernyshova, M.B. Permyakov // World applied sciences journal, 2013., № 27 (4), P. 437-443. 